\title{
LECTURER PROFESSIONAL DEVELOPMENT PROGRAM STRATEGIES AT PUBLIC STATE UNIVERSITY
}

\author{
Abdul Rohman \\ Widyagama Mahakam Samarinda University \\ rohmanuwgm@gmail.com
}

\begin{abstract}
The purpose of this study was to describe the lecturer professional development program strategies. The data was collected by conducting interviews, observations, and documentation. The informants in this study were the member of university senate, rector, vice rector, the head and secretary of quality assurance institutions, the head and secretary of research and community service institution. The data analysis was done through a single case data analysis. The result of this study showed that the strategies used by state university in lecturer development program focusing on the noble values of the university's long-term strategic plans. There were authorized institutions, established groups of expertise field, guidebooks for lecturers' management, and the development philosophy. The strategies in developing the lecturer professionalism on education and teaching were done by sending them for further study a doctoral degree, giving assistance, conducting pedagogical workshop, foreign language workshop, in-service training, and integrated workshop. On the research field, qualitative and quantitative research workshop were conducted. Creating orientation on research development, research scheme, classification and funding. On the community service field, lecturer professional development program was done by debriefing and forming a communitybased service.
\end{abstract}

Keywords: Strategy, professionalism, development

\section{INTRODUCTION}

The purpose of higher education can be achieved if the university is managed professionally by using patterns of an educational system that can produce skilled, flexible and adaptive human resources. This is in accordance with the demands of the effect of globalization as presented by Mercer (2010). The evidence of the effects of globalization in the world of education is to change education policies around the world. Governments in a country certainly make a change movement in the education system to produce more skilled, more flexible and more able to adapt the human resources. Globalization emphasis on leaders today to jump on management activities that follow the principles of human and propriety, as well as seeking the positive side of competition through strategies that can increase motivation, build strengths for organizational improvement, and produce a value-added performance. In short, all colleges are now being asked to move up to the level of productivity and performance that only a few universities could achieve.
Nowadays all colleges are required to move towards becoming world-class universities.

In general, the condition of human resources in universities in Indonesia still needs to be done a lot of development. Related to human resources in higher education, in the category of lecturers stated currently there are still more than 25,000 lecturers in Indonesia with the last education of bachelor degree, whereas as mandated by Law Number 14 Year 2005 on Teachers and Lecturers, educators in Higher Education must be educated at least masters degree. Furthermore, related to the competence of lecturers in international publications produced by the Indonesian lecturers are still too low when compared with international publications produced by the lecturers in some countries in the ASEAN region (Higher Education Strategic Plan 20162019). Even Mukti (2017) as the Director General of Science and Technology Resources and Higher Education reveals some problems resources Indonesian universities, including there are still many lecturers who do not qualify 
for minimum education (merely bachelor degree), the number of professors who possess doctoral degree is still lacking, many lecturers who have not had an academic position, the number of professors is still very small, and scientific publications of lecturers/scientists and intellectual property rights are still very low.

Seeing the condition of lecturers in Indonesia as conveyed by Director General of Science and Technology Resources and Higher Education, universities need lecturer development strategies in its management to become a world-class university. Strategies for the present are great for organizational leaders because of their involvement in preparing future plans for organizations on finance, growth, product innovation, developing new marketing and improving internal efficiency. In general, Ritson (2013) says strategy as a future action plan, which is usually done by senior management with a high level of ability. Strategic programs are organized developments of potential and functional sources of resources that include finance, processing, marketing, technology, human resources and so on. The strategy is the use of all available resources in the pursuit of a predetermined goal.

Lecturer management strategy is very important for universities because lecturers are the spearhead in learning activities. Therefore, the use of appropriate strategies to improve the professionalism of lecturers becomes very important to improve the quality of learning towards a world-class university. Bagheri (2016) stated that one of the strategic sources for organizations is human/lecturers because humans are an important component of the strategic plan.

The research conducted by The Future of Work Survey, Guest et al $(2000 \mathrm{~b}$ in Armstrong 2006) states that higher human resource development program activities are associated with higher levels of commitment and contribution to employees and then linked to higher levels of productivity and service quality better. Dutakk (2014) suggests training and development needs by developing programs for innovation in educational activities and leading to improved quality of education. Wei (2008) a company that conducts an internally consistent and competitive human resources development activity is believed to be the leading doers.

The importance of lecturer development program for the management of universities that ultimately encourages the quality of student learning becomes the main reason for researchers to conduct research under the title of Lecturer Professional Development Program at two State Universities in Malang.

\section{METHOD}

This research used qualitative research methods because in the object of research related to the problems on how professionalism lecturer development program strategy was done. The research process involved emerging problems, procedures, data specifically collected through participant settings, the analysis data was built from special to general, the researcher made interpretations of the data. The final report had a flexible structure, as suggested by Creswell (2009) and Hammersley (2013).

This study used single-case design. It needed a natural approach to get the focus of research on lecturer professional development program strategy. Ulfatin (2017) said that techniques of data collection were done by observation, in-depth interviews and documentation at one public university. Data analysis as suggested Miles (2014), researchers performed data analysis concurrent with data collection. This helped researchers in the field to cycle back and forth between thinking about existing data and moving strategies to collect new data, to get better data so that data analysis was done continuously. Thus data analysis and data collection began early. Qualitative data analysis was done through preparing and processing data, coding, data collection, data presentation, and conclusion or data verification.

After finding the theoretical theory from Case, it was then analyzed by comparing the theory in one case to another to find the difference, the simultaneous characteristics of Case, and Case to build a theory-based conception to develop substantive. Testing the validity of Ulfatins' (2017) suggestion data with credibility is to find out how the results match 
with reality, transferability where the researcher tried to expose the data and describe the findings in detail and systematic so that the results could be transferred to another situation, dependability to see the consistency of the findings research and confirmability to see how objectivity as in quantitative research.

\section{RESULTS}

Based on the overall data exposure of lecturer professional development program strategy, the following research results were obtained.

\section{Aspects of Main Strategies of Lecturer Professional Development \\ Findings on Aspects of Main Strategies of Lecturer Professional Development}

The general strategy used by Case to produce professional lecturers started with a long-term strategic plan of the University, which included the direction of lecturers' development in line with the direction of University development. The University has a long-term plan from 2011 to 2030. Development of the University until 2030 is divided into four stages 1) The year 2011-2015 as the stage of Transition and Reform as the Public Service Agency is the stage of implementation of planned renewals with the spirit of the learning university, namely selforganizing through institutional arrangement and human resources (HR) in a sustainable manner, 2) 2016 - 2020 as Consolidation and Reorientation stage is a consolidation phase of the new institutional implementation with orientation to the development of the field of education and non-education with a steady support system management and healthy funding at this stage also has planned an integrated physical development system in establishing Case to the International College, 3 ) the year 2021- 2025 as a stage of General Autonomy is the stage of implementation of the university into a stable independent corporation upholding the principles of autonomy of transparency and accountability, 4) the year
2026 - 2030 as a stage of Improvisation is the implementation stage of becoming an established university having high organizational resilience and possessing strong internal and external competitiveness.

Regarding the strategic plans, the vision and mission were created. In which, it says that University is a college of reference, in line with the vision and mission. To achieve the vision and mission, the University uses five development principles that give full attention to all parties to grow. Development is based on the following five principles. (1) System thinking, which is a frame of mind that gives an opportunity to all parties within the university to learn that the university is a unity consisting of different objects. (2) Personal mastery, which is an individual commitment to the learning process so that each personality has a reliable ability in the field he is engaged in. (3) Mental models, namely assumptions, principles, and generalizations that are strongly bonded firmly held by every individual and organization that affect how to understand the college. (4) Shared vision, namely the equation of thinking patterns, attitudes, and patterns of action to achieve a shared vision that can create a common identity in an atmosphere of togetherness. (5) Team learning, which is the accumulation of individual learning that animates all team members in developing an open communication and sharing meaning and understanding.

On the other hand, the development program in Case in the period of 2015-2019 is formulated as strategic vision "GURU" or ungGUlan dan RUjukan to be translated as superior and referral. In order to have the professional lectures to achieve the predetermined strategic vision "GURU", one of the ways was to make regulations on the senate of the university through meetings. Some policies issued by university leaders developed the lectures' professionalism. On the level of professor, there was a requirement to make a roadmap based on their expertise. The groups of professors are required to build the roadmap. Those who are other than professors should have their own field of expertise. In order to maintain the academic capability as lecturers, the groups of field expertise are created. 
Accordingly, this group was a group of non-professor, a lecturer with the education background of a doctoral degree or below creating a group of field expertise, each major had lecturers with a field of expertise were based on their interest.

The existence of this field expertise group policy was a strategy used Case for professional lecturers in their field of expertise. Thus, the theme of teaching, research and community service included in guiding students related to the theme of their expertise. In this group, lecturers include teaching tasks, research, guiding students' thesis, and testing. Then, the University always encouraged lecturers in the academic field in conducting research, dedication to the writing of the paper was more focused on the works of interest, meaning that their expertise was the most prominent where no origin of dedication or research topics they participated.due to this, it was also to assure the area of expertise and to help that if the person was promoted his credit score was clear, so if that dedication, or scientific work up to what he teaches it accordingly. It was due to the University did not want to have a lecturer who held the Course $\mathrm{x}$, but what they were engaged in was Course $z$, then the results of the study were not able to enrich the insight and content of learning.

The lecturer who was the expert on a certain field would make it easier both for internal matters related to Tridharma, or to promote the university potential to outside world. The units which were doing the lecturers'professional development duty based on their expertise are in their own units. The quality assurance institute was only a controller, not an executor; the development was in the unit in each faculty.

On the other hand, lecturers' development activities are carried out by Case in the form of

1) increasing lecturer involvement in various scientific events at national and international level; 2) developing a conducive and active learning community at various levels (a group of expertise, study program, faculty, graduate, and Research and Community Service Institute) in order to increase the capacity and productivity of lecturers in academic work. 3) improvement of frequency/stability, and scope of seminar/symposium /exhibition of art/technology products held by the University; 4) development of cooperation network with universities and /or professional associations to strengthen scientific journals; 5) young lecturers coaching; 6) development of utilization of human resources by outsiders, 7) increasing cooperation with universities at home and abroad

\section{Aspects of Lecturer Professional Development Strategy in the Field of Education and Teaching}

The finding showed that formal education for a lecturer on Case was a doctoral degree, so the duty of university was to encourage them who still possess a master degree to continue to a doctoral degree and the major should be related to the major and field of study abroad. The reasons why having to go abroad were to be able to learn outside, have a growing insight, and be in line with institutional needs. Having a doctoral degree was a requirement for lecturers, yet for those who were constrained by the age factor were not qualified for the study designation, they were still given the opportunity to study with the independent funding and the university only supported some cost. For those who get study permit must have carried out their main work.

The strategy of developing lecturer professionalism in the field of education and teaching besides through further study of doctoral degree was also through training, it was given because many lecturers had a pure science background, meaning they did not have knowledge on how teaching was given to improve skill with AA program, applied approach, and character, improvement of instructional and moral skills. In one semester the lecturers were trained how to teach, how to make evaluation tools, how to manage the class, how to carry out the lesson, continue their practice in their respective classes, observed at the end of their semester shared best practices about what they did even though they were master degree or doctoral degree, as long as they 
were of pure science they were obliged to follow the program.

The institutions or units who signed the character training and AA were handled by the institutions of education and teaching development. While for the trainings related to research and community service are handled by the research and community service institution. After lecturers completed the character trainings and AA, the lecturers' performance on the teaching field would be controlled by the quality assurance unit. While at the faculty level, the lecturers would be monitored on how their teaching preparation is, including their discipline in teaching.

Besides the character training and AA programs, the development programs conducted in Case to develop lecturers' professionalism to encourage them. The purposes were to enable the lecturers to do an exchange abroad, to experience in other universities. In addition, the availability of fundings from the International Development Bank (IDB) enabled the lecturer to do internships, three-month workshops, or conducting research in universities abroad.

The activities carried out to support the lecturers' development on the field of education and teaching are namely 1) development of teaching and learning based on the research result, 2) improving the quality of lecturers in implementing quality learning,3) facilitate the participation of lecturers in academic and nonacademic activities on national and international level, 4) carrying out academic and nonacademic activities on national and international level, 5) Developing the learning standars, 6) Exhibition on academic products on national and internationallevel, 7) Evaluating the Lecturer Workload, 8) carrying out in Service training, lesson study and related activities, 9) Assigning and providing of further study cost assistance abroad and within the country, 10) sending out the lecturers with student status to join a sandwich program and mentoring the candidate of sandwich program, 11) to facilitate the scheme candidate for Scheme for Academic Mobility and Exchange (SAME) and dissemination of SAME results.

\section{Aspects of Lecturer Professional Development Strategy in the Field of Research}

The findings presented below were the result of interviewing the respondents on how the university strategy in improving the lecturer professionalism in the research field.

Rector's policy stated that one lecturer should have one publication within a year, and the lecturers were encouraged to conduct joint research with other reputable universities. Those who had a doctoral degree are given the facilities to do research, uploaded to international journals to achieve professorship. Lecturers who wanted to pursue the professorship are given the facilities because universities considered that the professors were the leading components of the university.

The policy that requires one lecturer to have one publication is control by remuneration. When within the semester there was a lecturer who could provide the publication, thus they could not receive the remuneration 100 percent. In fact, the lecturers who were capable writing reputable journal articles would be given an incentive of 10 million Rupiahs, non-reputable journal article was 6 million rupiahs, with moderate reputations in national levels would also be registered to remuneration and be given incentive.

Next, the findings on the activities
program to improve the lecturers'
professionalism obtained from various documentation sources. The activities were interdisciplinary research development through the empowerment of lecturers and students between education and non-education programs within the campus, across universities within a country and across countries, the continuous improvement of lecturers'capability on research/development and publication, improvement on service/facilities for lecturers to publish/ exhibit, development of lecturers'research roadmap, publications of lecturers'innovative masterpieces, the development of a research governance system that refered to national standards of higher education, development on mentoring system, financing, awards on scientific publications, 
enhanching cooperation with research institutes at homecountry and abroad.

The findings of the types of activities to support the research development strategy 2016-2020 include: the development of research themes (grand design) that could be followed up with community service activities both local, regional and national, improving the quality and quantity of research lecturers, editor of expert journal articles, improving the writing of scientific papers through workshops, workshops, which led to quality and quantity for journal data base, reference book writing, monograph, and teaching materials based on research results and community service, quality improvement and quantity of scientific publications, development and improvement of research quality, improvement of student involvement in research activities, enhancement of research cooperation with other relevant institutions or institutions, training and mentoring of scientific publication at national and international level, development of potential scientific papers to obtain Intellectual Property Rights (IPR), facilitate the dissemination of IPR. Improving the internet access service for learning, improving e-journal, and e-book services. In addition, increasing participation in student work contest in the field of research, developing the competence and professionalism of lecturers in preparing proposals, conducting professional research, producing qualified intellectual property, and being able to implement the results of advantageous work.

\section{The findings of Aspects of Lecturer Professional Development Strategy in the Field of Community Service}

The strategies used by Case in improving the lecturer professionalism were done by constructing strategic planning of year of service. This document was a guidebook in carrying out the year of service. The strategic plan document in Case in the year of 2016-2020 consisted of five main chapters.

In the year of service strategic plan document stated that there were several activities regarding the professional development. The activities were quality improvement program including workshops on the period of service on basic and advanced levels at least once a year. The workshop/basic level dedication training is intended for the implementation of the beginner devotion. Advanced training workshops were dedicated to senior service practitioners with the aim of being able to carry out national/international service dedication and/or being able to publish their work in reputable international journals and /or able to achieve IPR.

The implementation of community service was regulated professionally in Strategic Plan 2016-2020 starting from planning, implementation and reporting have been made the standard process as in the document.

\section{DISCUSSIONS}

Aspects of lecturer professional development strategy included the section stated in article 60 of Law and Lecturer Law in 2005 that in carrying out their professional duties, the lecturer is obliged to carry out education, research, and community service as well as in the Lecturer Career Development Information System Manual published by the Directorate General Higher Education in 2012 expressed the elements of academic activities that become the main task of lecturers consists of education and teaching, research and community service.

\section{Main Strategy Aspect of Professionalism Development}

Common mistakes in organizations that want to make improvements but they do not determine where the organization's position and what changes it wants in the future (Camero and Quinn, 2011). Improving the resources required for planning, Ulfatin (2018) states that resource planning begins with an internal and external factor analysis. From the results of the analysis are known between the comparison of needs and availability of resources. The results of this study inform clearly that the development of lecturer professionalism refers to the roadmap or long-term strategic plan of the university. As Bryson (2005) argues that strategic planning has become a way of life of government organizations and non-profit organizations since the strategic plan has been proven to improve change, higher organizational accountability, 
and better management, stakeholders both managers, clients.

The organization exists because there is a goal to be achieved, how goals are made and how to achieve that goal is management. The function of planning according to Robbins (2013) is to direct the organization's goals clearly, to create an overall strategy to achieve that goal, and develop a plan to integrate and coordinate all activities.

The management of lecturers' development is regulated by the university by establishing institutions that are given greater authority in managing lecturers' development. The institution is a quality assurance institution. As regulated in Indonesian PP. No. 4 Year 2014 on the Implementation of Higher Education and Management of Universities, is required to organize a unit or regulatory body and a quality assurance. The authority and job description of this institution are on the quality of all activities of units in universities. Thus, almost all activities in the college environment must have clear standards and quality procedures.

Each organization has its own values which are the values of the organization's culture and understood by all members of the organization. Case has the identity as The Learning University that makes it as a character, even cultural behavior for all the elements in Case to always improve the individuals and organization. Marquardts (2002) culture refers to values, beliefs, actions, rituals and habits that help shape behavior and patterns of perception, in cultural organizations making learning an integral part of all organizational functions. Robbins (2013) says that the culture arose from the founders' philosophy and continued to influence those who joined later as the organization grew. Lapina (2015) and Wei (2008) say that organizational culture has a direct influence on the effectiveness and performance of the organization. The stronger the organizational culture the more effective the organization is. The campus organizational culture forms the basis for quality management and is directly related to the development program.

There are two types of lecturers who are given the opportunity to develop the ability and professionalism with the funding is borne by the university, they are civil servants and public agency lecturer, the same treatment in terms of funding by the university can give a work satisfaction for lecturers. Robbins (2001) explained that the work satisfactory is a general attitude of a person towards their job. Nasser (2010) also states that lecturer satisfactory in the development program is very important to design and refine the coming development programs.

\section{Strategy Aspect of Profesional Development on Education and Teaching}

Quality of learning to students is determined and very closely related to lecturers. In learning with students in the class of lecturers are required to have professional skills in their field and have pedagogic competence, personality, professional and social. The purpose of professional development of lecturers in the field of teaching is the more quality and quality of learning with students as well as increasing productivity and a more competitive work. To achieve this expectation, one of the efforts is to require lecturers to obtain the highest qualified education (Doctorate), as suggested by Bubb (2007) continuous professional development of lecturers can be done by continuing education, assistance, and training. A competent lecturer will no longer be competent in the future (Skinner, 2005) because of pedagogical content knowledge, knowledge of content knowledge, knowledge of the curriculum knowledge fast, so lecturers have to keep learning. Then Robbins (2001) says many organizations spend millions to finance formal training for their employees. Neil (2003) states that knowledge about the course there are three areas of pedagogical content knowledge, knowledge of the subjects taught (content knowledge), curriculum (curriculum knowledge). Case becoming a world-class university, the knowledge of the three of knowledge was not enough to be applied in the course if not matched with the ability of lecturers in Foreign Language. So it is appropriate if you want to improve the competitiveness of institutions, lecturers need to be equipped with foreign language skills. As suggested by Kamaruddin (2010), from the results of his research stated that lecturers need 
to improve their English skills especially listening, speaking and writing skills as a form of professional development.

\section{Strategy Aspect of Profesional Development on Research}

Professionalism of lecturers in the field of research is one of the demands that must be fulfilled in addition to the field of education and teaching, Research is an activity conducted according to scientific principles and methods systematically to obtain information, data, and information related to understanding and /or testing a branch of knowledge and technology, Kemenristek Dikti (2006).

The task of research is the task of lecturers in addition to teaching can be done by producing scientific papers, translating /adapting scientific books, editing/editing scientific papers, making plans and works of patented technology, and, making design and technology work, design and artwork monumental / literature work. In order for lecturers to reach the level of professionalism as mentioned above, lecturers on Case findings are given qualitative research training and quantitative research, which in itself is also given insight into the methodology. Lecturers are also given research development orientation as well as research scheme. The research scheme is to provide clumps of expertise as a researcher, while the classification of research to provide the level of expertise as researchers starting from young researchers, novice and expert researchers. Development programs in the field of research conducted by Case above is an attempt to develop professionalism of lecturers in the field of research amid busy lecturers in carrying out teaching tasks. Gibb (2016) said that research and publication of scientific papers is the main challenge faced by academics in college in the middle of teaching duties and responsibilities, many teaching hours, a large number of students, high hopes of results. As a result, Smalley (2017) said that many researchers complain that many lecturers do not do learning based on the results of research. In other words research and teaching seem to have no relationship, resulting in a gap between teaching and research.

\section{Strategy Aspect of Profesional Development on Service}

The third aspect of the Tridharma lecturer is the dedication to society. It needs professional ability so that the dedication done to the community contributes and adds value to society. Professional lecturers understand that research is an activity that is conducted according to scientific principles and methods systematically to obtain information, data, and information related to understanding and / or testing of a branch of knowledge and technology as stated in the documents of the Ministry of Research and Technology of Higher Education 2006). The task of conducting research is a task in the field of research and development of scientific papers can be in the form of producing scientific papers, translating/adapting scientific books, editing/editing scientific papers, making plans and works of patented technology, and create design and work of technology, design and artwork monumental / art performances / literary works.

To be able to perform the duties of professional service, lecturers are equipped with workshops/training of basic level service and advanced service and guided by a strategic and standard dedication from planning, implementation, and reporting.

The ministry of higher education (2014) stated that the main duty of the lecturers in performing higher education is one unity dharma or activity, because the other two dharmas are only able to be differentiated but not separated, because they are related to each other and support each other.

\section{CONCLUSIONS}

Lecturer professional development cannot be conducted without planning. In order to achieve the target of lectures' development, the senate of the universities needs to encourage the deans of faculties, heads of units, and senior lecturers as well as the experts in the universities. They are called Strategic Planning Team (SPT), they are the motor drive of planning preparation.

Planning process by the team can be done in several stages. Thus, what needs to be done by this team is constructing a schedule. 
The first schedule is to identify the owned noble values, whether those values are still worthy to reserve or need replacing. The noble values, jargon or moto used can be made sure still have meanings for one long period of twenty to twenty-five years ahead. Next is identifying/ analyzing the condition of the higher education nowadays, the identification is done for things that are the successes, obstacles, and challenges faced. The analysis is not only on education fields but also the economic trends, finance, marketplace and also social and culture. Once the recent condition is known, the next step is to find out the answers for twenty or twenty-five years in the coming period of what condition is expected. In achieving the target, there needs to be planning for middle term period which can be four of five years, and each of the period is the stepping stones to reach the long-term goals. Thus, every midterm period needs a target to be achieved. In achieving the midterm target, every period the human resources, facilities, and finance needed to achieve the predetermined plans are estimated.

In relation to the development of lecturers' professionalism, the annual notice begins to decide the corresponding institutions which will be given the mandatory in managing the lecturer, and also decide what major programs are going to be used to make the lecturers become expert. Besides, there should be another training called Continuing Professional Development (CPD) in which the direction is in line with the higher education long-term strategic plans. All in all, monitoring and supervising are needed to make sure that the development programs stay on the right path.

\section{REFERENCES}

Bagheri.J. Overlaps between human resources' strategic planning and strategic management tools in public organizations. Procedia Social and Behavioral Sciences 230 (2016) 430438 dari www.sciencedirect.com

Bryson.J.M.,Alston. F.K. 2005. Creating and Implementing Your Strategic Plan. USA:John Wiley \& Son, Inc
Bubb,S., Early,P.2007. Leading and Managing Continuing Professional Development. London: Paul Chapman Publishing

Crewell, J.W.2009. RESEARCH DESIGN qualitative, quantitative, and Mixed Methods Approaches.California: SAGE Publication, Inc.

Direktorat Jendral Pendidikan Tinggi

Kementrian Pendidikan dan

Kebudayaan (2014). Pedoman Operasional Penilaian Angka Kredit Kenaikan Pangkat/Jabatan Akademik Dosen

Duta.N., Panisoara.G.,Panisoara.I.O. The Profile of Teaching ProfessionEmpirical Reflections on the Delopment of the Competences Of UniversityTeacher. Procedia Social and Behavioral Sciences 140 (2014) 390-395 dari www.sciencedirect.com

Gibbs.A.2016. Improving Publication: advice for busy higher education academics. International Journal for Academic Development: Routledge Taylor and Francis Group

Kamaruddin. W., Ibrahim.M.S. Enhancing Malaysian Polytechnic Technical Lecturers' Competency through the Identification of Professional Development. Procedia Social and Behavioral Sciences 7 (C) (2010) 446-454 dari www.sciencedirect.com

Lapina. I., Kairisa. I.,Aramina,D.2015. Role of Organization Culture in the Quality Management of University. $20^{\text {th }}$ Internasional Scientific Conference Economics and Management. Procedia Social and Behavioral Sciences 213 (2015) 770-774 dari www.sciencedirect.com

Marquardt.M.J.2002. Building The Learning Organization. USA. Davies-Black Publishing

Mercer, J.,Barker, B.,\&Bird, R.2010. Human Resource Management in Education. New York:Routleedge

Miles, M.B.,Huberman, M.A., Saldana, J.2014. Qualitative Data Analysis. Arizona 
State University. United State of America

Nasser.F., Shabti. A. Satisfaction with Professional Development. Procedia Social and Behavioral Sciences 2 (2010) 2739-2743 dari www.sciencedirect.com

Ritson, N.2013. Strategic Management $2^{\text {nd }}$ edition. Neil Ritson \& bookboon.com

Robbins.S.,Timothy. 2013. Organizational Behavior, 15th Edition. England: Pearson

Education Limited Edinburgh Gate Harlow Essex CM20 2JE

Robbins.S. Organizational Behavior. New Jersey. Prentice Hall. Inc

Smalley.L.A.,Rau, B.L.,Neely,A.R., Evan,W.R.2017.Factors Perpetuating the Research Teaching Gap in Management: A Review and
Propositions. The International Journal of Management Education. 15 (2017) 501-5012

Skinner.D.2005. Get Set for Teacher Training.

Finland: Edinburgh University Press.

Ltd

Ulfatin,N.2017. Metode Penelitian Kualitatif di Bidang Pendidikan. Teori dan Aplikasi. Malang: Media Nusa Creative

Ulfatin.N.2018.Manajemen Sumber Daya Manusia Bidang Pendidikan. Depok: PT Rajagrafindo Persada

Wei.L.,Liu J., Zhang, Y.,Chiu,R.2008. The Role of Corporate Culture in The Process of Strategic Human Resource Management: Evidence from Chinese enterprises. Human Resource Management. Winter, Vol.47 No. 4, Pp 777-794: Wiley Interscience 